\title{
The Multiple Middlegrounds Between Civil and Criminal Law
}

\author{
Franklin E. Zimring†
}

My reactions to Kenneth Mann's original and insightful essay are organized under four headings. Part I offers a short recital of the academic complaints that are a compulsory part of this sort of exercise. Part II outlines three different types of middleground innovations between civil and criminal law and argues that the type of innovation chosen is a significant element in the calculus of the due process standards that should be imposed on governmental action. Part III suggests that the growth of administrative government and the need for administrative agencies to control their own enforcement agendas are the dominant reasons for the evolution of punitive civil sanctions at the federal level. Other factors Professor Mann lists, such as burden of proof and procedural protection for defendants, hold much less significance in explaining the boom in middleground civil sanctions. Finally, Part IV suggests that as the number and kind of criminal sanctions expand, the case for allowing punitive civil remedies rests on the comparative advantage of agency-managed enforcement efforts.

\section{Definitional Issues}

Professor Mann's "middleground" article is open-ended to a fault in two respects: a number of key terms in the article are never defined, and the due process calculus with which Professor Mann would replace the characterization of sanctions into the civil or criminal rubric is totally unspecified. At both the front and back end of his argument, then, Professor Mann leaves too much to the reader's imagination.

The most striking nondefinition in the article is the argument's central term-the "punitive civil sanction." Professor Mann fails to define that key phrase or any of its constituent terms. I take it that the label "civil" applies to any proceedings so labeled by a legislature. But what is a "sanction"? Any money collected by government from private parties? Monies or other conse-

† William G. Simon Professor of Law and Director, Earl Warren Legal Institute, University of California at Berkeley. 
quences due as a result of a breach of duty or promise? Are my annual income taxes sanctions? What about the interest due if I do not pay my taxes on time? The percentage penalty the IRS collects for civil fraud? Without a conceptual definition of the term "sanction," the subject of the article remains unspecified.

The failure to define the term "punitive" further compounds this mystery, which in turn leads to some waffling about what the author means by "punitive civil sanction." Early on, he tells us that he will argue for calling all "morethan-compensatory" money sanctions punitive. ${ }^{1}$ But the author never fully defines "compensatory," and his article later speaks as if larger than compensatory monetary transfers may have nonpunitive motivations and justifications. ${ }^{2}$ Without any notion of what the author regards as punitive and why he does so, the distinction between punitive and other types of money sanctions is obscured.

This is particularly confusing because he fails to define the other adjectives affixed to money sanctions as well. The article includes a lengthy discussion of what it calls a deterrence rationale in civil cases, and contrasts it with what it calls punitive sanctions. The distinction is difficult to grasp because the author defines neither "deterrent" nor "punitive." Is the former only instrumental and the latter only condemnatory? If so, all real world examples would be composites of the "ideal types" in Professor Mann's scheme. One who doubts that punitive and deterrent rationales can be clearly distinguished, as I do, will not find reassurance in the author's inattention to definition.

The lack of a principled definition of deterrence in Mann's article may also explain why he allows the jurisprudence of monetary sanctions to paint itself into the following corner: The idea that these sanctions are deterrent and not punitive procedures reduces them in size and prevents lawmakers from setting monetary sanctions at levels that are high enough to exploit the full deterrent potential of a fully developed regime of monetary sanctions. ${ }^{3}$ The author cites no authority for this extraordinary paradox, and my own reading of deterrent rationalizations points in the opposite direction. Deterrence rationales in criminal law are notoriously open-ended, always available to justify an escalation in penalty as long as a harm to be deterred still exists. ${ }^{4}$ By contrast, theories of just desert actually may have upper boundaries that are easier to find. But all this assumes that Professor Mann's definition of deterrence is the same as that of most other commentators in the field of criminal law. One strand of tort theory worries about overdeterrence, the reduction of productive noncriminal behavior below optimal levels. ${ }^{5}$ In contrast, most literature is unconcerned with the overdeterrence of bank robbery. Which deterrence doctrine does Professor

1. Kenneth Mann, Punitive Civil Sanctions: The Middleground Between Criminal and Civil Law, 101 YALE L.J. 1795, 1815 (1992).

2. See, e.g., id. at 1823-37.

3. Id. at 1839.

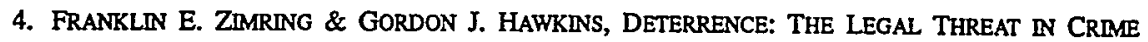
CONTROL 37-42 (1973).

5. RICHARD A. POSNER, ECONOMIC ANALYSIS OF LAW 176 (3d ed. 1986). 
Mann have in mind? The article could have brought more order to the confusions now found in case law and academic analysis had it paid more attention to these definitional niceties.

The second loose end in the article's analysis is the lack of a due process framework. Professor Mann argues for a functional jurisprudence in which due process standards governing both the burden of proof and procedural protections related to privacy and dignity increase in civil cases with the severity of the potential consequences. ${ }^{6}$ But in his article, this outcome appears as an end without a means because he does not present the framework he would use to create such a sliding scale. Once he shows congressional willingness to extend a low "one size fits all" threshold of civil case protection, some constitutional standards seem necessary to the establishment of a sliding scale of procedural protection. But how are we to achieve that protection?

The author justly criticizes the rather arbitrary pattern of bifurcating cases into civil and criminal categories and of providing high-end due process protection only to those cases classified as criminal. He also implicitly rejects a functional jurisprudence that would classify more cases as criminal in nature and thus use criminal procedure as the method of reaching larger constitutional protections.

Perhaps it is premature to reject the convenient peg of a civil-criminal distinction without some attention to alternative constitutional mechanisms available to structure and justify procedural standards. Heightened protection in civil cases usually occurs in situations that involve the risk of secure confinement, such as juvenile court delinquency jurisdiction and involuntary civil commitment under the mental health powers, or the loss of personal associations, such as child custody. ${ }^{7}$ Do any of these cases provide a better foundation for sliding-scale due process standards in civil monetary sanction cases than the civil-criminal dichotomy? If not, how should a framework be constructed to support a sliding scale result?

\section{MIDDLEGROUND INNOVATIONS}

A variety of importantly different middleground sanctioning systems is evolving in the United States, and the appropriate procedures to govern such systems might depend on the type of middleground system instituted and on the motive for its establishment. Three distinctions between types of middleground innovations deserve attention in a discussion of the appropriate legal treatment of civil sanctions: the distinction between middleground criminal sanctions and innovative civil sanctions; the distinction between civil sanctions

6. Mann, supra note 1, at 1870-71.

7. See, e.g., Santosky v. Kramer, 455 U.S. 745 (1982) (termination of parental rights); Addington v. Texas, 441 U.S. 418 (1979) (civil commitment proceeding); In re Gault, 387 U.S. 1 (1967) (delinquency proceeding in juvenile court). 
designed as alternatives to criminal processing and those meant to supplement the criminal process; and the distinction between administratively delivered and judicially determined civil sanctions. Understanding this diversity of middlegrounds clarifies the issues involved in choosing procedural standards for punitive civil sanctions.

Recently, a diversification in the sanctions available through the criminal law has paralleled the diversification of civil sanctions. The federal criminal code of 1984 greatly expanded the range of criminal fines, ${ }^{8}$ and both federal and state criminal sanctions now include options like restitution, the payment of some enforcement costs, and reparative remedies such as community service. ${ }^{9}$ This diversification of the criminal sanction is directly relevant to the expansion of civil sanctions in two ways. First, the development of criminal sanctions in new directions suggests that the desire to avoid procedural protections associated with criminal prosecution is not the sole force behind the trend toward more diversified sanction systems. The same forces are evidently at work within the criminal justice system.

Second, the increased variety of criminal sanctions alters the opportunity costs associated with the restriction of civil sanctions. If only civil sanctions could provide very large money fines, the comparative advantage of large fines would become part of the argument for supporting the civil sanctioning system. Once the criminal law catches up with administrative systems in the size and variety of available money sanctions, the case for a civil system must rest on considerations other than the types of sanctions available. As a matter of moral proportionality, it would be perverse to maintain a system in which larger sanctions are available in civil proceedings than in criminal ones. So it seems preferable to have a system in which the case for civil proceedings rests on elements other than the adequacy of available sanctions in criminal cases.

Among civil sanctioning systems lies a very important distinction between civil mechanisms designed to displace criminal proceedings and civil systems erected only to supplement the risks and punishments of criminal prosecutions. Professor Mann seems to assume that civil sanctions function as an alternative to more vigorous criminal prosecutions.

It lessens the need to use the criminal law to sanction wrongs and permits a more flexible response to the wrongful conduct.... While the reach of the criminal law has expanded consistently, the availability of punitive civil sanctions has avoided some of the inflation of criminal laws that would otherwise have occurred. ${ }^{10}$

8. 18 U.S.C.A. §§ 3571-3572 (West 1985 \& Supp. 1991).

9. See, e.g., 18 U.S.C.A. $\& 3663$ (West 1985 \& Supp. 1991); N.Y. PENAL LAW $\S 60.27$ (McKinney 1992); NORVAL MORRIS \& MICHAEL TONRY, BETWEEN PRISON AND PROBATION (1990).

10. Mann, supra note 1 , at 1863. 
But does this mean that the federal and state legislators who voted for broad civil drug forfeiture laws were trying to discourage the criminal prosecution of drug traffickers? Civil regimes like drug forfeiture ${ }^{11}$ and $\mathrm{RICO}^{12}$ are meant to be supplements; they add more punishment and deterrence to that imposed in the criminal process and give law enforcers a second chance at punishment if the criminal prosecution misses its mark. Any diversion from criminal prosecution would disappoint most of those who enacted a forfeiture statute.

Thus, not all middleground systems serve the same function; some supplement criminal sanctions while others provide alternatives to them. Even if many civil penalty systems divert pressure from criminal prosecutions, others supplement those prosecutions. The effect of civil programs is an empirical question to which an answer based on generalization from a small number of cases is particularly hazardous. Whether and when civil sanctions lead to an "attenuated role of criminal prosecution"13 is not yet known but well worth discovering.

Some forms of procedural protection restrict supplementary but not alternative sanctioning systems. For example, since double jeopardy protections force a choice between civil and criminal remedies, the law enforcer who simply wishes to use the civil route as an alternative to criminal prosecution is not concerned with them. ${ }^{14}$ However, double jeopardy restrictions might constrain supplementary uses of the civil option. In this sense, old-fashioned procedural devices may provide discriminate protection in modern settings.

The third key distinction between types of middleground sanctions concerns the degree of sanctioning power held by administrative agencies rather than courts. In the federal government, regulatory agencies can neither prosecute nor judge criminal matters. Agencies must persuade U.S. Attorneys or the Department of Justice to initiate prosecution. This means that tax fraud must compete with postal theft and water pollution for the U.S. Attorneys' attention. In contrast, if the civil regulatory scheme conferred the prosecutorial power on an administrative agency, that agency could set the agenda. Tax matters would compete only with other tax matters, not with postal theft. Most civil sanctioning systems extend further and also give substantial judicial power to administrative agencies in such cases. These systems thus confer power on regulatory agencies to control their own agendas, power that they lack in criminal proceedings.

11. 28 U.S.C.A. $\$ 881$ (West 1981 \& Supp. 1992).

12. 18 U.S.C. \& 1964 (1988).

13. Mann, supra note 1 , at 1863 .

14. See United States v. Halper, 490 U.S. 435 (1990) (holding civil penalty barred by double jeopardy after defendant had been convicted for crime based on same facts). The decision pointedly observed: "Nothing in today's ruling precludes the Government from seeking the full civil penalty against a defendant who previously has not been punished for the same conduct, even if the civil sanction imposed is punitive." Id. at 450. 
The basic appeal of administrative civil proceedings over criminal prosecution lies not in matters of proof or procedural nicety but in the larger power of administrative agencies in such cases. In this sense, the growth of civil punitive sanctions may have much more to do with power distributions among the branches of government than with the burden of proof or procedural requirements in criminal cases.

\section{ADMinISTRATIVE GOVERNMENT}

The growth of administrative government in the federal system seems to be both the most important explanation for the historical increase in civil sanctions as well as the most significant issue affecting their future. Professor Mann attributes some of the growth in civil sanctions to this feature, but I think it is necessary to emphasize this element when assessing responsibility for the growth of the civil middleground. The growth of administrative agencies responsible for regulating a particular subject matter-banks, environmental protection, or highway safety-generates a tendency to grant authority to enforce substantive regulatory rules to these specialist agencies. The use of the criminal sanction lies outside the immediate control of the specialist agency as a matter of constitutional law and governmental organization: criminal matters must be tried in Article III courts and must be prosecuted by the Department of Justice. However, the civil sanction relocates prosecutorial authority and adjudicatory power in the administrative agency.

The strongest evidence for the dominant role of the growth of the administrative branch of the federal government in the evolution of these sanctions is the uneven use of civil sanctions at various levels of American government. While civil sanctioning systems have exploded in the federal government, this pattern has no parallel in state or local government. At the state level, civil sanctions may grow when state administrative agencies develop in the federal pattern, but without this administrative government there is no structure to support the civil sanction. In the modern city, even the issuance, adjudication, and enforcement of parking fines remains within the criminal justice system! ${ }^{15}$ No other branch of government can absorb this type of function at this level of government.

This need for administrative structure to foster civil sanctions may lead to paradoxical statistics on criminal and civil sanctions. Those areas where administrative governance grows most quickly may also experience a large expansion in criminal prosecutions over the same time period. This, however, would not be a decisive rebuttal of Professor Mann's theory that civil sanctions can divert cases away from criminal processes because the same social changes that produce more governmental attention may cause the expansion of both civil and

15. 60 C.J.S. Motor Vehicles $\S \S 25,28$ (1969 \& Supp. 1991). 
criminal cases. Without the civil sanctioning system, the growth in criminal cases might have been even greater.

Still, if expansions in administrative attention are a prerequisite to growth in civil sanctions programs, the smart money would bet against any reduction in criminal complaints as an automatic concomitant of the development of civil sanctions. The use of civil sanctions as a substitute for criminal prosecutions depends on either the administrative agency or the U.S. Attorney, the gatekeeper of prosecution, declining to press criminal charges because of the civil alternative. How often and in what circumstances this happens are empirical questions whose answers may lie in the twentieth-century archives of administrative government.

Pending clarification of the historical record, it seems prudent to assume that an increase in civil sanctions usually reflects the judgment that a particular problem area requires more government regulation than the criminal law can provide, independent of whether that expanded civil attention reduces the pressure on the criminal justice system. If that is the historic pattern, one's enthusiasm for the punitive civil sanction in a particular area will depend largely on one's view of the desirability of expanded government regulation in that area.

\section{CONCLUSION}

My argument for the centrality of administrative government in the growth of civil sanctions is partly a logical process of elimination and partly an historical analysis. Civil sanctions are not inherently better suited to responding to harmful behavior because any sanctions available to civil processes are also within the reach of the criminal law. If the comparative advantage of the civil system were merely a matter of streamlined procedures or easing the burden of proof, any criminal justice system that depends on plea bargaining could achieve the same low-cost penalty determinations by exchanging leniency for procedural rights. It is the capacity of administrative agencies to control civil sanctions, to bring such systems almost totally within the sphere of administrative control, that seems to be the most important factor in the growth of these sanctions.

Whether the civil sanction is appropriate then becomes a question of the optimal scale of governmental regulation. This is a question that Professor Mann addresses only implicitly, if at all. But if one is ready to conclude that many modern problems need more government than the criminal law can provide, what does this mean for the shape of the sanctioning system that should result?

Without detailing a middleground jurisprudence of my own, two narrow points and one broader one emerge from the preceding discussion. First, if procedural shortcuts are not the major advantage of the civil punitive sanction, 
rigorous procedural protections can constrain the sanctioning process without sacrificing the central comparative advantage of the civil sanction. Second, if the supplemental civil sanctions available in formats like civil RICO and drug forfeiture are less important than administrative alternatives to criminal proceedings, perhaps some form of election of remedies can discourage supplemental proceedings without having a derogatory impact on alternative sanctioning proceedings.

The broader point illustrated by these possibilities is that it might not be difficult to accommodate both the interests served by strict rules of procedural due process and the governmental interests at the core of the trend toward civil punitive sanctions. Furthermore, the possibility of such an accommodation is not irrelevant to the prospects for heightened due process protections in civil punitive sanction cases. The Supreme Court has used the kind of pragmatic functional analysis that highlights these possibilities to detail due process requirements in parental rights cases and delinquency proceedings. ${ }^{16}$ Perhaps what is good for Gerald Gault is good for General Motors as well.

16. Compare In re Gault, 387 U.S. 1 (1967) (holding that to guarantee fundamental fairness various due process requirements must be fulfilled in adjudging delinquency in juvenile court proceedings) with In re Winship, 397 U.S. 358 (1970) (in juvenile proceedings, due process requires proof beyond a reasonable doubt that act would constitute crime if committed by adult) and McKeiver v. Pennsylvania, 403 U.S. 528 (1971) (jury trial not constitutionally required in adjudicative phase of juvenile court proceedings). 